\title{
Findes der moralsk realisme i den Hebraiske Bibel?
}

\author{
Om at stille moralen op over for $\mathrm{Gud}^{1}$
}

\author{
Professor, dr.theol. \\ Jan Dietrich, Aarhus Universitet
}

\begin{abstract}
The problem of moral realism does not seem to play a major role in the Hebrew Bible. However, some texts like Genesis 18 and others do show that this problem was a pressing one for at least some Old Testament writers, and that it was coped with through arguing with God. Taking Genesis 18 as an exemplary case, this article displays the conditions for the possibility of moral realism in the Hebrew Bible as well as some threads of its unfolding.
\end{abstract}

Keywords: Abraham - disputation - ethics - Eutyphro dilemma - divine law - justice - moral realism

\section{Eutyfrons dilemma}

Måske var den egentlige årsag til anklagen mod Sokrates ikke, at han var ugudelig eller fordærvede ungdommen, men at han forstyrrede Athenerne med kloge spørgsmål. Den såkaldt "elenktiske" (eller "sokratiske") diskussionskunst afslører viden som pseudo-viden, og sådan noget skaber forargelse. ${ }^{2}$ Sokrates blev anklaget for blasfemi og indfandt sig ved porten til forhallen ind til den såkaldte archon basileus, embedsmanden der var ansvarlig både for kultisk lov og for drabssager. ${ }^{3}$ Ved porten mødte han Eutyfron, en af disse gudfrygtige personer, der tror at vide alt, og som opfylder deres religiøse pligter med den bedste samvittighed. Eutyfron ville anklage sin far på grund af en drabssag, og han gik ud fra, at sådan en anklage er en from pligt, og at den vil sone besmittelsen (miasma), som fulgte af hans fars

1. Denne artikel er en lidt udvidet udgave af min tiltrædelsesforelæsning, som jeg holdt den 8. februar 2019 på Aarhus Universitet. Jeg takker mine to kolleger, Else Kragelund Holt og Hans Jørgen Lundager Jensen (begge Aarhus) for at rette mit danske. En tysk version af denne artikel vil blive publiceret i $Z T h K 116 / 3$ (2019).

2. Jf. fx Otto Leggewie, i: Platon, Euthyphron. Griechisch/Deutsch. Übersetzt und herausgegeben von Otto Leggewie (Stuttgart: Reclam 2012), 68.

3. Jf. fx Reginald E. Allen, Plato's 'Euthyphro' and the Earlier Theory of Forms (London: Routledge 1970), 15. 
gerning. ${ }^{4}$ Guden Kronos havde jo kastreret sin far Uranos på grund af hans ugerninger, og Zeus havde lagt sin far Kronos i lænker på grund af dennes egne ugerninger. Så kunne man vel også anklage sin egen far for drab. ${ }^{5}$ Hvad gjorde Sokrates? Han gjorde, hvad han var bedst til: Han begyndte at stille spørgsmål, og sagen udviklede sig til et principspørgsmål om, hvad fromhed egentlig er. ${ }^{6}$ Den hovmodige Eutyfron prøvede tappert at svare, indtil han irriteret gav op og løb sin vej, så dialogen endte på bedste sokratiske vis - dvs. på tankevækkende vis - uden løsning, i en apori.

"Overvej nu følgende: Bliver det fromme elsket af guderne, fordi det er fromt, eller er det fromt, fordi det elskes?" (Eutyfron 10a). ${ }^{7}$ Dette er det afgørende spørgsmål i dialogen. Er det fromme - som senere bliver identificeret som noget retfærdigt - en størrelse sui generis, endda stillet op over for guderne - altså en ide som eksisterer i kraft af sig selv, uafhængig af en guddommelig vilje? Eller bliver det fromme defineret af Gud og er afhængig af Guds vilje, så blasfemi og drab i en anden verden kunne være gode gerninger, hvis Gud blot ønsker det? Er det gode godt, fordi Gud vil have det sådan, eller vil Gud noget, fordi det er godt? Er det retfærdige en norm uafhængig af Gud, en uafhængig målestok, sin egen instans, der ud fra sig selv er en normgivende instans? ${ }^{8}$ Det er Eutyfrons dilemma, som skelner mellem moralsk realisme og moralsk voluntarisme. ${ }^{9}$ Den sokratiske dialog når ikke til en løsning, selvom det er tydeligt, at Sokrates foretrækker den første mulighed. ${ }^{10}$ Denne første mulighed har ifølge Kurt Bayertz

4. Om pligtens etiske og religiøse dimensioner jf. Saskia Peels, Hosios. A Semantic Study of Greek Piety. Mnemosyne Supplements 387 (Leiden: Brill 2016), 41f.

5. Sådan en anklage ville hverken følge sædvane eller ret i Athen. Jf. Allen (1970), 20-23. 6. Jf. fx Leggewie (2012), 73.

7. Platon, Samlede Verker i ny oversattelse. Bind 1. Udgivet af Jorgen Mejer og Chr. Gorm Tortzen (København: Gyldendal 2013), 70.

8. Selvom Eutyfron regnes med til Platons tidlige dialoger, enten til de tidlige (Vlastos) eller til overgangen til mellemperioden (Gigon, Rufener), er der alligevel allerede her en sokratisk idélære, som ikke ligger alt for fjernt fra Platons senere idélære, jf. Günter Figal, Sokrates (München: Beck ${ }^{3} 2006$ ), 20.64-85 i tilknytning til Allen (1979), 67-166; jf. også Thomas D. Paxson, "Plato’s 'Euthyphro' 10a to 11b”, Phronesis 17 (1972) 171-190 (175). For eksempel bruges der allerede begreberne idea og eidos under dialogen om fromheden (Eutyfron 5d, 6d-e); jf. Allen (1970), $28 f$.

9. Jf. fx Kurt Bayertz, Warum überhaupt moralisch sein? (München: Beck 22014), 82f. I den teologiske diskurs optræder moralsk voluntarisme gerne under begrebet 'teologisk voluntarisme' eller Divine Command Ethics, jf. fx Lois Malcolm, "Divine Commands", i: red. Gilbert Meilaender \& William Werpehowski, The Oxford Handbook of Theological Ethics (Oxford: Oxford University Press 2005), 112-129, og mht. Det Gamle Testamente: John Barton, Ethics in Ancient Israel (Oxford: Oxford University Press 2014), 127-156.

10. Eutyfrons definition, at fromheden er det, som elskes af guder, hhv. (bedre) som elskes af alle guderne, bliver modbevist. Validiteten bag ved denne gendri- 
en teologisk "ubehagelig" implikation, fordi Gud bindes af et princip, som er uafhængigt af ham. ${ }^{11}$ I det følgende vil jeg gerne vise, at det er præcis denne teologisk "ubehagelige" position, som også findes på flere udvalgte steder i den hebraiske Bibel. ${ }^{12}$ Den mest berømte tekst herom findes i 1 Mos 18. I denne tekst forhandler Abraham med Gud om Sodomas og Gomorras tilintetgørelse og stiller følgende spørgsmål til Gud:

Skulle han, der dømmer hele jorden, ikke øve ret? ${ }^{13}$ (1 Mos 18,25).

At denne teologisk "ubehagelige" position overhovedet var mulig at tænke, er ikke en selvfølgelighed. Tværtimod - Eutyfrons dilemma har ikke spillet nogen rolle i store dele af den gammeltestamentlige litteraturudvikling. I de tidlige højkulturer omkring bl.a. det gamle Israel, Ægypten og Mesopotamien fandtes der ingen funktionel uddifferentiering mellem sædvane, moral og ret. ${ }^{14}$ Der fandtes heller ingen funktionel sondring mellem religion og ret. Den sidste instans og grundlaget for retten var Gud. Mika 6,8: "Menneske, du har fået at vide, hvad der er godt, hvad Herren kræver af dig", er blot det mest kendte citat for denne voluntaristiske position. Hvordan kunne der på denne baggrund overhovedet udvikle sig en slags gammeltestamentlig version af Eutyfrons dilemma, hvor Gud og retfærdighed stilles op over for hinanden?

velse er omdiskuteret; mht. en positiv bedømmelse jf. fx Laszio Versényi, Holiness and Justice. An Interpretation of Plato's Euthyphro (Washington: University Press of America 1982), 67-88.

11. Jf. fx Bayertz (22014), 82f. Mht. Eutyfrons problem i filosofi- og teologihistorien, jf. fx William J. Wainwright, Religion and Morality (Aldershot: Ashgate 2007), 73-83.

12. Eutyfrons dilemma sættes allerede i forbindelse med 1 Mos 18,25 af Mordecai Roshwald, “A Dialogue between Man and God", SJT 42 (1989), 145-165 (151f). Jf. også Jaco Gericke, The Hebrew Bible and Philosophy of Religion (Atlanta: SBL 2012), 405-446 vedr. flere gammeltestamentlige tekster.

13. Oversættelsen if. 1992-oversættelsen.

14. Mht. denne uddifferentiering jf. fx Norbert Hoerster, Was ist Recht? Grundfragen der Rechtsphilosophie (München: Beck 2006), 10f. I Det Gamle Testamente bliver sædvane, moralnormer og love subsumeret under begreberne ret og retfærdighed, jf. fx Jan Assmann, "I. Ägypten: Die Idee vom Totengericht und das Problem der Gerechtigkeit”, Gerechtigkeit. Richten und Retten in der abendländischen Tradition und ihren altorientalischen Ursprüngen, red. Jan Assmann, Bernd Janowski \& Michael Welker (München: Fink 1998), 10-19 (10f). 


\section{Religionshistoriske forudsætninger}

En første, men i sig selv ikke tilstrækkelig betingelse for muligheden for at udvikle en idé om moralsk realisme, der kan sættes over for Gud, findes begrundet i den religionshistoriske idé om retten som oprindelig selvstændig guddom og dens udvikling til en af Guds virkningsmagter. I det gamle Mesopotamien findes ret og retfærdighed, kittum og mišarum, ikke kun som verdens grundprincipper, men de kunne selv anses som guder. For eksempel kunne de optræde som guderne Nigzida und Nigsisa eller sidde som den "retfærdige dommer" og "himlens og jordens dommer" ved solguden Shamashs højre og venstre side; ${ }^{15}$ lignende formuleringer findes i Mari med gudeparret

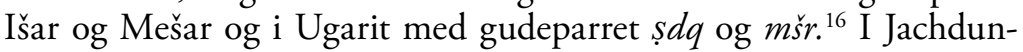
Lims byggeindskrift fra Mari opstilles gudeparret kittum og mǐsarum således som relativt selvstændige væsener ved solgudens side. Solguden er dermed i mindre grad rettens kilde og mere dens hyrde, hvorfor Shalom Paul betegner retten som et "metadivine realm". ${ }^{17}$ Derudover findes i det gamle Mesopotamien idéen om skæbnen, som har eksisteret som et selvstændigt element på linje med guderne, og guderne kan være modtager eller herre over skæbnen og skæbnetavlerne. ${ }^{18}$ Desuden anses de såkaldte ME som grundlæggende virkningsmagter og ordensprincipper i verden, som nok er blevet opstillet af guderne, men som alligevel har en vis uafhængighed, fordi de kan transporteres rundt imellem guderne (ved gavegivning eller ved rov). Og blandt disse ME'er findes karakteristisk nok principperne "ret" og

15. Jf. CAD s.v. kittu A samt CAD s.v. mišaru A; Manfred Krebernik, "Richtergott(heiten)", RlA 11 (2006-2008), 354-361 (354).

16. Jf. RS 24.271:14 = KTU 1.123:14. Jf. Dennis Pardee, Ritual and Cult at Ugarit (Atlanta: SBL 2002), 151.

17. Shalom Paul, Studies in the Book of the Covenant in the Light of Cuneiform and Biblical Law, (VT.S 18) (Leiden: Brill 1979), 6; jf. også Rainer Albertz, "Die Theologisierung des Rechts im Alten Israel”, Religion und Gesellschaft. Studien zu ihrer Wechselbeziehung in den Kulturen des Antiken Vorderen Orients, red. Rainer Albertz, AOAT 248 (Münster: Ugarit 1997), 115-132 (116) med note 3f, og mht. skæbnetavlerne: Jack N. Lawson, The Concept of Fate in Ancient Mesopotamia of the First Millennium. Toward an Understanding of Šimtu (Orientalia Biblica et Christiana 7) (Wiesbaden: Harrassowitz 1994), 39.

18. Jf. Kai Lämmerhirt \& Annette Zgoll, "Schicksal. A. In Mesopotamien”, RlA 12 (2009-2011), 145-155 (148); Piotr Steinkeller, "Luck, Fortune, and Destiny in Ancient Mesopotamia - Or How the Sumerians and Babylonians Thought of Their Place in the Flow of Things", Fortune and Misfortune in the Ancient Near East. Proceedings of the 60th Rencontre Assyriologique Internationale at Warsaw 21-25 July 2014, red. Olga Drewnowska, Margorzata Sandowicz (Winona Lake: Eisenbrauns 2017), 5-24 (18-20). 
"retfærdighed" (kittum og mī̌sarum). ${ }^{19}$ Idet retten kan tænkes som en (delvist personificeret og deificeret) størrelse uafhængig af de enkelte guder, er det ikke underligt, at guderne kan kritiseres for deres umoralske gerninger, og at de kan konfronteres med moralske principper. ${ }^{20}$

I Syrien-Palæstina var retten oprindeligt en selvstændig guddom med navnet Ședeq ("retfærdighed"), som stadig ses i Bibelen i personnavne Malkîședeq ("Min konge er Șædæq": 1 Mos 14,18; Sl 110,4), 'Adonîṣadaq ("Min herre er Șædæq": Josva 10,1.3) og ved den jebusitiske præstenavne Sādôq (fx 2 Sam 8,17), og ekstrabibelsk ved personnavnene Rabi-șidqi fra et Amarna-brev (EA 170,37) samt i talrige personnavne fra Fønikien og Ugarit med elementen $s d q$, for eksempel $s d q$-mlk eller $s d q-s ̌ l m .{ }^{21}$ Muligvis er guddommen Șadaq blevet identificeret i Jerusalem med guddommen Šàlèm, den deificerede sol eller aftenstjerne, der findes flere steder, ikke kun uden for Bibelen, men også i bibelske personnavne som Jerusalem, Absalom eller Salomo. ${ }^{22}$ I Det Gamle Testamente overtager Gud selv attributterne fra denne gud samt fra Shamash, den mesopotamiske solgud, der, når han står op om morgenen i øst, afsiger dom og holder verdensordenen i gang. Ret og retfærdighed gælder her som midler til at opretholde og genoprette verdensordenen. ${ }^{23}$

19. Mht. de såkaldte ME, jf. Anglika Berlejung, Die Theologie der Bilder. Herstellung und Einweihung von Kultbildern in Mesopotamien und die alttestamentliche Bilderpolemik (OBO 162) (Fribourg/Göttingen: Universitätsverlag/Vandenhoeck \& Ruprecht 1997), 20-24; Hans Heinrich Schmid, Gerechtigkeit als Weltordnung. Hintergrund und Geschichte des alttestamentlichen Gerechtigkeitsbegriffes (Tübingen: Mohr Siebeck 1968), 61-66.

20. Se nedenfor, afsnit 4 mht. enkelte eksempler fra den gamle Mesopotamien. Mht. Det Gamle Testamente, se fx Sl 82.

21. Jf. sammenfattende fx Helmer Ringgren, "ṣādaq", ThWAT 6 (1989), 898-903 (903); Schmid (1968), 11f; se også Amoritternavnet Ammișaduqa; jf. Bernard F. Batto, “Zedeq", DDD (21999), 929-934 (930). Mht. en pilespids fra Libanon med personnavnet jtr-șdq, jf. Othmar Keel, Die Geschichte Jerusalems und die Entstehung des Monotheismus. Teil 1, OLB IV,1 (Göttingen: Vandenhoeck \& Ruprecht 2007), 190 og 156, figur 101.

22. Jf. Herbert B. Huffmon, "Shalem", DDD (21999), 755-757; mht. spørgsmålet om solguden fra Jerusalem og identificering af denne med Jahve, jf. overblikket i Keel (2007), 190f og 273-286 (med yderligere litteratur).

23. Jf. formuleringen i Hans Neumann, "Göttliche Gerechtigkeit und menschliche Verantwortung im alten Mesopotamien im Spannungsfeld von Norm(durch)setzung und narrativer Formulierung”, i: Heinz Barta/Robert Rollinger/Martin Lang (udg.), Recht und Religion. Menschliche und göttliche Gerechtigkeitsvorstellungen in den antiken Welten (Wiesbaden: Harrassowitz 2008), 37-48 (39). Vedr. et overblik jf. Schmid (1968), 13-77; Bernd Janowski, Rettungsgewißheit und Epiphanie des Heils. Das Motiv der Hilfe Gottes "am Morgen" im Alten Orient und im Alten Testament 1. Alter Orient, WMANT 59 (Neukirchen-Vluyn: Neukirchener Verlag 1989). 
Vejen fra en selvstændig guddom til Guds "ontologiske virkningsmagt” er ikke lang. I det gamle Egypten får gudinden Ma'at en mellemposition: På den ene side er hun både en selvstændig gudinde og et abstrakt princip, der står for sandhed og retfærdighed, som guder og mennesker har brug for; ${ }^{24}$ på den anden side bliver hun selv til solgudens attribut, som når dennes øjne og legeme, kød, ånd, hjerte og kappe siges at bestå af Ma'at. ${ }^{25}$ I Det Gamle Testamente agerer şedeq som en af Guds "ontologiske virkningsmagter" (Sl 85,11-14; cf. 89,15) ${ }^{26}$ og kan sammen med retten, mišpatt, udgøre fundamentet til gudstronen (Sl 89,15; 97,2; cf. Es 9,6; Ord 16,12; 20,28). ${ }^{27}$ Der findes lignende formuleringer i Egypten om gudinden $\mathrm{Ma}^{2} \mathrm{at}^{28}$ og i Mesopotamien om guderne Kittum og Mǐšrum. ${ }^{29}$ På et rullesegl fra den oldakkadiske tid (ca. 2250 f.Kr.), bemærkelsesværdigt nok fundet i en grav i Jerusalem fra det 7. årh. f.Kr., ses de guddommelige tjenere Kittum og Mǐšrum at flankere solguden på sin trone. ${ }^{30} \mathrm{Sl}$ 17,1 synes at identificere Jahve og sadeq, ${ }^{31}$ og i Es 45,8 hedder det, at Gud har skabt ham (Ședeq) - en tanke, der kun ved første blik synes at være inkompatibel med en forestilling om moralsk realisme, men som principielt ikke strider imod en sådan, eftersom retten anses som en af Guds skabninger, og som dermed forekommer at være forstået som en relativt uafhængig størrelse.

Noget lignende gælder for naturens regler. Gud giver ikke kun mennesket retningslinjer, men pålægger også naturen regler. ${ }^{32}$ Flere gange siges det, at Gud pålægger stjernerne love (huqqôt) (Jer 31,35f; 33,25; Job 38,33). ${ }^{33}$ De står ikke som overordnede over Gud, men

24. Jf. Jan Assmann, Ma'at. Gerechtigkeit und Unsterblichkeit im Alten Ägypten (München: Beck 1990).

25. Jf. Hans Bonnet, Reallexikon der ägyptischen Religionsgeschichte (Berlin: de Gruyter 1952), 430; Schmid (1968), 48.

26. Jf. fx Klaus Koch, "צדק", THAT 2 ('2004), 507-53 (519).

27. Mht. "retlinethed" (mîšor) parallelt med șadaq jf. Es 11,4; Sl 45,7f; 98,9; jf. Keel (2007), 191; Reinhard Müller, Jahwe als Wettergott. Studien zur althebräischen Kultlyrik anhand ausgewählter Psalmen, BZAW 387 (Berlin/New York: de Gruyter 2008), $178 f$.

28. Jf. H. Brunner, "Gerechtigkeit als Fundament des Thrones", VT 8 (1958), 426428; Reinhard Grieshammer, "Maat und Șädäq. Zum Kulturzusammenhang zwischen Ägypten und Kanaan”, GM 55 (1982), 35-42.

29. Jf. Schmid (1968), 76; Keel (2007), 191; Müller (2008), 99-102.

30. Jf. Keel (2007), 277f med figur 154.

31. Dette fremgår ikke helt af DO 1992, hvor der er lavet en tekstrettelse, så passagen her lyder "Herre, hør en retfærdig sag".

32. Når vi taler om 'naturlove', overfører vi metaforisk anskuelser fra den sociale verden på naturen.

33. Jf. Konrad Schmid, "Der vergessene Orient. Forschungsgeschichtliche Bestimmungen der antiken Ursprünge von 'Naturgesetzen'”, Laws of Heaven - Laws of Nature. Legal Interpretations of Cosmic Phenomena in the Ancient World, red. Konrad 
som kun relativt uafhængige fænomener. Derfor kan Gud også bryde naturlovene, for eksempel da han lod solen stå fast på himlen under kampen mod amoritterne (Josva 10,12-14).

Selvstændige guddomme, gudernes “ontologiske virkningsmagter”, skabte principper og regler fremkommer som relativ uafhængige størrelser, som i sig selv ikke kan begrunde en moralsk realisme. Men de udgør dog en religionshistorisk betingelse, for at der kan opstilles moralske principper over for Gud. ${ }^{34}$ Yderligere betingelser kommer til, som det skal ses i de følgende afsnit.

\section{Litteraturhistoriske forudsætninger}

Den gammeltestamentlige retshistorie begynder, uden at Gud spiller nogen særlig rolle. Den ældste kasuistiske retssamling i Det Gamle Testamente er den såkaldte Pagtsbog (2 Mos 20,22-23,33), som traditionelt dateres til omkring 700 før Kristus. Pagtsbogen samler eksisterende sædvaneret, tilføjer enkelte konkrete retsbeslutninger fra vanskelige retssager og udvider det hele ved associationer og analogidannelser i den retslærde skolekontekst.

I den Gamle Orient bliver sådanne retssamlinger opfattet som kongeret. Det er ikke guderne, der giver lovene, men kongen. Som gudernes stedfortræder får kongen opgaven og magten til at sætte retten igennem i landet, idet han garanterer legitimiteten af retssamlinger som kongeret, udsteder konkrete love og afgør problematiske retssager som højeste dommer. På den berømte Hammurapi-stele fra Babylon overgiver solguden Shamash ring og stav til kong Hammurapi, så kongen kan udstede alle de love, der følger på stelen i sit eget

Schmid \& Christoph Uehlinger, OBO 276 (Fribourg/Göttingen: Universitätsverlag/Vandenhoeck \& Ruprecht 2016), 1-20 (12f). Lignende gælder for den gamle Orient, jf. det såkaldte Lied auf Anu jf. Adam Falkenstein/Wolfram von Soden, Sumerische und akkadische Hymnen und Gebete (Zürich: Artemis 1953), Nr. 20,19f: "Des (Himmels) Regeln hat er recht gefügt - im Himmel und auf Erden beugt sich ihm jeder." Sociale og naturlige love kan korrespondere. Jf. fx Ass. A I 31-36 "[Sîn und Ša]maš, die Zwillingsgötter, hielten, u[m] einen Rechtsentscheid nach Recht und Gerechtigkeit (dèn kitte u mišarí) de[m Land] und den Leuten zu schenken, Monat für Monat die Bahn von Recht und Gerechtigkeit ein ... ." Oversættelsen if. Stefan M. Maul, "Der assyrische König - Hüter der Weltordnung", i: Assmann/ Janowski/Welker (1998), 65-7 (66); transkriptionen jf. Rykle Borger, Die Inschriften Asarhaddons, Königs von Assyrien, AfO.B 9 (Graz: Selbstverlag 1956), 2.

34. I Sodomahistorien, hovedeksemplet nedenfor, synes der 'bag om' den foreliggende tekst at have været en tradition om solgudens domsafgivelse ved solopgang - som her er blevet overført til Gud, jf. Othmar Keel, "Wer zerstörte Sodom?", ThZ 35 (1979), 10-17. 
navn. Ret og retfærdighed kommer fra solguden; men det er kongen som solgudens stedfortræder og udtrykte billede, ${ }^{35}$ der implementerer solgudens principper i form af konkrete love. Det vil sige, at kongen skaber den materielle ret som sit herskerinstrument, ${ }^{36}$ mens retten som sådan, principperne ret og retfærdighed, gælder som en størrelse, der er overordnet over kongen. ${ }^{37}$ Ved nytårsfesten skulle de babylonske konger derfor stå til ansvar over for guderne, idet de ydmygt skulle vise, at de selv havde holdt sig til retfærdigheden. ${ }^{38}$ I Det Gamle Testamente findes en lignende retsforståelse i Salme 72 - dog med en lille, men vigtig forskel:

Gud, overdrag dine domme til kongen,

din retfærd til kongesønnen,

så han dømmer dit folk med retfærdighed

og dine hjælpeløse med retsindighed ${ }^{39}$ (Sl 72,1f).

Bliver retfærdigheden elsket af kongen, fordi retten er overordnet over ham, eller er det retfærdige retfærdigt, fordi kongen elsker det? Dette spørgsmål kan det Gamle Testamente nemt besvare. Kongen får ikke kun retten og magten til at gennemføre retsbeslutninger, men, i modsætning til den Gamle Orient, også de konkrete retsregler og love fra Gud. ${ }^{40}$ Guds lov står over kongen, og derfor bliver for eksempel kong Davids gerning mod Urias ikke ustraffet. I øvrigt sætter

35. Hammurapi betegner sig selv som 'sol/solguden fra Babylon' (CH V 4f).

36. Jf. Schmid (2016), 18.

37. Kongen udgiver love som sin egen ret, men er selv underordnet under den guddommelige jurisdiktion, jf. Neumann (2008), 40.

38. Jf. fx Karlheinz Kessler, "Gott - König - Tempel. Menschliches Recht und göttliche Gerechtigkeit in neu- und spätbabylonischer Zeit”, i: Barta, Rollinger \& Lang (2008), 73-92 (75).

39. Oversættelsen if. 1992-oversættelsen.

40. Jf. fx Martin Arneth, "Sonne der Gerechtigkeit". Studien zur Solarisierung der Jahwe-Religion im Lichte von Psalm 72 (Wiesbaden: Harrassowitz 2000), 129; Bernd Janowski, "Die Frucht der Gerechtigkeit. Psalm 72 und die judäische Königsideologie", "Mein Sohn bist du" (Ps 2,7). Studien zu den Königspsalmen, red. Eckart Otto \& Erich Zenger, SBS 192 (Stuttgart: Katholisches Bibelwerk 2002), 94-134 (119f); Reettakaisa S. Salo, Die judäische Königsideologie im Kontext der Nachbarkulturen. Untersuchungen zu den Königspsalmen 2, 18, 20, 21, 45 und 72, ORA 25 (Tübingen: Mohr Siebeck 2017), 238. Mht. den Syrisk-Palæstinensiske kontekst jf. Jan Dietrich, "Psalm 72 in its Ancient Syrian Context", Mediating Between Heaven and Earth: Communication with the Divine in the Ancient Near East, red. Anna Zernecke, Jonathan Stökl \& Carly L. Crouch, LHB/OTS 566 (London: T\&T Clark 2012), 144-160. 
5 Mos 17 toraen over kongen, og kongen skal, ligesom en elev, læse i den hele tiden. ${ }^{41}$

Hvis de gammeltestamentlige retssamlinger stammede fra den Gamle Orient, ville de være kongelige retsbøger, udgivet og legitimeret af kongen. Men dette er altså ikke tilfældet. Tværtimod forstås den ældste bibelske retssamling, Pagtsbogen, ikke som en kongelig retssamling. Den bliver - ved hjælp af sekundære tilføjelser - indrammet som en guddommelig lov. Gud optræder som subjekt og taler med Israel, som tiltales i anden person. Endvidere begrundes retskravene eksplicit, især med henvisning til Guds barmhjertighed. ${ }^{42}$

Hvis du tager en anden mands kappe i pant, skal du give den tilbage til ham før solnedgang. Det er det eneste, han har at dække sig med; det er den kappe, han skal have på kroppen; hvad skal han ellers sove i? Når han råber til mig, hører jeg ham, for jeg er nådig ${ }^{43}$ (2 Mos 22,25f).

I den gammeltestamentlige litteratur bliver loven legitimeret som guddommeligt indstiftet og åbenbaret. Måske var sådan en udvikling først mulig i den kongeløse tid; men sandsynligvis blev den allerede lanceret i og med den profetiske socialkritik. ${ }^{44}$ Herefter gælder samtlige gammeltestamentlige retssamlinger og bud som givet af Gud,

41. Mht. denne karakter som "konstitutionel kongedom" jf. Norbert Lohfink, "Die Sicherung der Wirksamkeit des Gotteswortes durch das Prinzip der Schriftlichkeit der Tora und durch das Prinzip der Gewaltenteilung nach den Ämtergesetzen des Buches Deuteronomium (Dtn 16,18-18,22)", Testimonium Veritati. Philosophische und theologische Studien zu kirchlichen Fragen der Gegenwart, red. Hans Wolter, FTS 7 (Frankfurt am Main: Knecht 1971), 143-155; Bernard M. Levinson, "The Reconceptualization of Kingship in Deuteronomy and the Deuteronomistic History's Transformation of Torah", VT 51 (2001), 511-534.

42. Mht. teologiseringen af loven jf. Eckart Otto, Theologische Ethik des Alten Testaments (Stuttgart/Berlin/Köln: Kohlhammer 1994), 81-111; Albertz (1997), 120122; Konrad Schmid, Gibt es Theologie im Alten Testament? Zum Theologiebegriff in der alttestamentlichen Wissenschaft, TS 7 (Zürich: TVZ 2013), 79-85; Reinhard G. Kratz, Historisches und biblisches Israel. Drei Überblicke zum Alten Testament (Tübingen: Mohr Siebeck $\left.{ }^{2} 2017\right)$, 111-117. Ifølge Hermann Spieckermann, "Recht und Gerechtigkeit im Alten Testament. Politische Wirklichkeit und metaphorischer Anspruch", Recht - Macht - Gerechtigkeit, red. Joachim Mehlhausen (Gütersloh: Kaiser 1998), 253-273 (254), betegner mišpāt "die konkrete Rechtsetzung und Rechtsprechung", mens șadaq og ședaqāh primært angår "die umfassende Größe mit (Be)Gründungsfunktion, normativem Anspruch und wirklichkeitsprägender Kraft für Gegenwart und Zukunft".

43. Oversættelsen if. 1992-oversættelsen.

44. Sådan if. den klassiske opfattelse. Mht. en mulig sendatering jf. fx. Christoph Levin, "Das Amosbuch der Anawim", i: idem, Fortschreibungen. Gesammelte Studien zum Alten Testament, BZAW 316 (Berlin/New York: de Gruyter 2003), 265-290. 
og Gud selv gælder som kilde til loven. ${ }^{45}$ Denne såkaldte teologisering af loven er et særtræk for den bibelske retsforståelse i forhold til den fra den Gamle Orient og begrunder - som sagt med hjælp af senere tilføjelser - loven ud fra Guds væsen og hans handlinger, her især befrielsen fra Ægypten, og Guds barmhjertighed og hellighed. Lovens begrundelser som guddommelig ret indtræder dog ikke arbitrært, men for at give afgørende retsnormer et stabilt grundlag: For eksempel skal personsanseelse ikke forekomme, og man skal hellere ikke være bange for at stå for dette princip over for mægtige, 'fordi loven tilhører Gud', som det hedder ifølge den hebraiske tekst i 5 Mos 1,17. Interessant nok forhindrer denne teologisering af Loven ikke tankegangen om moralsk realisme, men var med til at befordre den. To argumenter støtter denne tese:

For det første: Teologiseringen af loven betyder, at kongen bliver afløst i sin rolle som den øverste dommer og erstattet med Gud. Gud er ikke kun verdens skaber, men også dens øverste dommer. Den øverste dommer (der altså oprindeligt var den kongelige dommer), er nødt til at holde sig til prædefinerede retsprincipper, ligesom i den Gamle Orient, hvis dommeren ikke vil være en tyran. En dommer kan derfor, i princippet, konfronteres med spørgsmålet om, hvorvidt han selv holder sig til loven eller ej. ${ }^{46}$ Det betyder: Det er først og fremmest den kongelige dommers rolle, som Gud overtager, der muliggør modsætningen mellem Gud og retfærdigheden. En væsentlig betingelse for muligheden for konfrontationen mellem gud og ret ligger begrundet i Guds rolle som dommer. ${ }^{47}$

For det andet: Teologiseringen af loven betyder, at der tilføjes eksplicitte begrundelser til lovene, så nogle forskere endda plæderer for at

45. Jf. fx Albertz (1997), 122.

46. Derudover synes konfrontationen mellem Gud og retten mulig pga. den juridiske interpretation af gudsforholdet i form af den internationale pagtaftale mellem storkongen (Gud) og vasallen (Israel) i lighed med gudsforholdet i form af ægteskabsretten mellem ægtemanden (Gud) og hustruen. Det ses især i 5 Mos., Hos. og Ez. Også til kontrahenten og ægtemanden kan spørges, om han holder sig til loven. Her muliggør pagtteologien og metaforiseringen af ægteskabsforholdet idéen om moralsk realisme. Mht. pagtteologien, jf. også Barton (2014), 135: "Seen from the point of view of moral (pre-)philosophy, the covenant idea is a kind of rationalization of an obedience ethic."

47. Jf. også Ehud Ben Zvi, "The Dialogue between Abraham and Yhwh in Gen. 18.23-32: A Historical-Critical Analysis”, JSOT 53 (1992), 27-46 (37f). I denne sammenhæng er også Sl 58 og 82 vigtige, fordi Gud her som den øverste dommer dømmer de andre guder pga. deres forkerte domsudsagn. Her bliver det klart, at rollen som dommer begrunder muligheden for at vurdere de falske guders handlinger i forhold til retsreglerne. Mht. S1 82 i retskonteksten jf. Bernd Janowski, "II. Israel: Der göttliche Richter und seine Gerechtigkeit", i: Assmann, Janowski \& Welker (1998), 20-28 (22). 
forstå lovene som "wisdom-laws". ${ }^{48}$ Begrundelserne appellerer tydeligvis til indsigten og fornuften for at garantere, at de guddommelige love accepteres. ${ }^{49}$ Lovene udstedes ikke arbitrært. Det førnævnte eksempel fra Pagtsbogen begrunder buddet om solidariteten med Guds barmhjertighed. Mange deuteronomiske sociallove fordrer solidaritet med de hjælpeløse med henvisning til empati, fordi 'du, Israel, har selv været træl i Ægypten, og fordi du ud fra din egen erfaring kender til den svages nød' (fx 5 Mos 15,12-15). Desuden findes andre begrundelser: Bestikkelse er forbudt, fordi det gør øjnene blinde (2 Mos 23,8). Under krig må fjendernes træer ikke fældes, fordi træer ikke er mennesker (5 Mos 20,19). Når trællen bliver frigivet i det syvende år, skal man give ham en rundhåndet gave med, fordi " $\mathrm{du}$ har tjent godt ved at have ham" (5 Mos 15,18). Kværnstene må ikke tages i pant, da det ville være, som om man tog skyldnerens eget liv som pant ( 5 Mos 24,6).

Sådanne begrundelser er retshistorisk nye og vigtige. De begrunder konkrete retsnormer på baggrund af en retsforståelse, der viser hensyn til de svage - i modsætning til Hammurapis kodeks, der ganske vist også betoner de svages beskyttelse, men kun i prologen og epilogen, som tydeligt afviger fra de gammeltestamentlige, da de konkrete love afspejler de givne hierarkiske forhold og mangler begrundelser. ${ }^{50}$ I Det Gamle Testamente er det anderledes, og det er baggrunden for Abrahams spørgsmål: Skulle han, der dømmer hele jorden, ikke øve ret? $(1 \text { Mose } 18,25)^{51}$ I 1 Mos 18 bliver det tydeligt, at retsideen er en normativ instans, som har en forpligtende virkning i sig selv. Hvad sker der præcis i den her tekst?

\section{Findes der moralsk realisme i den hebraiske Bibel?}

Første Mosebog kaldes også Genesis (“begyndelsen”), fordi her beskrives verdens 'urhistorie' og med patriarkfortællingerne og Josefnovellen oprindelses- og begyndelseshistorier forud for Israels historie. Genesis 18 er en del af Abrahamfortællingerne. Ifølge forskningen er patriarkfortællingerne ikke en oprindelig enhed og storfortælling, men er opstået på baggrund af oprindeligt uafhængige fortællekredse om Jakob, Isak og Abraham. Disse fortællekredse bindes sammen

48. Jf. fx Bernhard S. Jackson, Wisdom-Laws. A Study of the Mishpatim of Exodus 12:1-22:16 (Oxford: Oxford University Press 2006).

49. Jf. Barton (2014), 137-144.

50. Jf. Albertz (1997), 117.

51. Oversættelsen if. 1992-oversættelsen. 
ved hjælp af forjættelser, der løber igennem fortællingerne som en rød tråd. ${ }^{52}$ Den ældste litterære kerne om Abraham er Abraham-Lot-fortællingen, der omhandler Abrahams historie med Lot og løftet om Isaaks fødsel. ${ }^{53}$ Udgangspunktet er traditionen om Sodomas undergang, ${ }^{54}$ der skal forklare ørkenens oprindelse omkring Det Døde Hav: På grund af deres gerninger straffer Gud hele byen med dens fuldstændige undergang, idet han lader svovl og ild regne ned over byen. ${ }^{55}$ Kun Lot, Abrahams nevø, bliver frelst. Retsterminologi løber som en rød tråd gennem 1 Mos 18,16b-19,2956 og lader de forskellige afsnit fremstå som en større enhed, der omhandler retsspørgsmål.

I 1 Mos 18,22b-33, Abrahams dialog med Gud, diskuterer Abraham med Gud, om han virkelig vil tilintetgøre byen, selv hvis der

52. Jf. Jean Hoftijzer, Die Verheißungen an die drei Erzväter (Leiden: Brill 1956); Erhard Blum, Die Komposition der Vätergeschichte, WMANT 57 (Neukirchen-Vluyn: Neukirchener Verlag 1984); Matthias Köckert, Vätergott und Väterverheißungen. Eine Auseinandersetzung mit Albrecht Alt und seinen Erben, FRLANT 142 (Göttingen: Vandenhoeck \& Ruprecht 1988); Reinhard G. Kratz, "Die Verheißungen an die Erzväter. Die Konstruktion ethnischer Identität Israels", The Politics of the Ancestors. Exegetical and Historical Perspectives on Genesis 12-36, red. Mark G. Brett \& Jakob Wöhrle, FAT 124 (Tübingen: Mohr Siebeck 2018), 35-66.

53. 1 Mos 13; 18-19 og 21. Teksterne forudsætter forbindelsen med Isaakfortællingen. If. Hermann Gunkel, Genesis (Göttingen: Vandenhoeck \& Ruprecht ${ }^{6} 1963$ ), 159-162, udgør 1 Mos 12,1-8; 13; 18,1-16aа; 19,1-28.30-38 en oprindelig uafhængig legendekreds, jf. også Blum (1984), 273-289. Dog hænger 1 Mos 18,1-16a sammen med 1 Mos 21,1-7 og forudsætter forbindelsen med Isaak, jf. ibidem, 279.288. Teksten synes at være "eine einheitlich 'konzipierte', in wesentlichen Teilen neu gestaltete Komposition” (ibidem, 289).

54. Måske var også fortællingen om Abrahams gæstebud i Mamre en oprindelig selvstændig fortælling, jf. Jan Christian Gertz, "I. Tora und Vordere Propheten", i: Grundinformation Altes Testament. Mit Angelika Berlejung, Konrad Schmid und Markus Witte, red. Gertz (Göttingen: Vandenhoeck \& Ruprecht ${ }^{5}$ 2016), 275. I den endelige hebraiske tekst (der ikke indeholder navnet Abraham) knytter 18,1 sig dog "unmittelbar an 13,18 an und ist auf die vorgängige Nennung Abrahams als Subjekt der Handlung angewiesen." (Reinhard G. Kratz, Die Komposition der erzählenden Bücher des Alten Testaments. Grundwissen der Bibelkritik (Göttingen: Vandenhoeck \& Ruprecht 2000), 276. Vedr. den nordisraelitiske tradition om Adma og Zibojim, jf. Hos 11,8.

55. "Es ist das einzige Stück, das sich als selbständige Überlieferung isolieren läßt und von Abraham ursprünglich nichts weiß”, Kratz (2000), 276. At traditionen oprindelig er selvstændig, er også tydeligt i de øvrige tekster om Sodoma, der fokuserer på andre forbrydelser; jf. fx Es 1,10; 3,9; Jer 23,14; Ez 16,49, jf. Walther Zimmerli, 1. Mose 12-25: Abraham, ZB.AT 1.2 (Zürich: Theologischer Verlag 1976), 88. Selvom indledningerne i 1 Mos 18 und 19 er formuleret parallelt, er 1 Mos 18 formentlig knyttet til 1 Mos 19, ikke omvendt, jf. Kratz (2000), 276; anderledes fx Blum (1984), 280-282.

56. Jf. Ellen van Wolde, "Outcry, Knowledge, and Judgment in Genesis 18-19", Universalism and Particularism at Sodom and Gomorrah. Essays in Memory of Ron Pirson, red. Diana Lipton (Atlanta: SBL 2012), 71-100. 
findes et antal retfærdige i byen. Afsnittet er sandsynligvis et senere indskud ${ }^{57}$ der afviger tydeligt fra det foregående. ${ }^{58}$ Lige før, i vers 21 , taler Gud endnu en gang, ligesom ved Babelstårnet: "Jeg vil gå ned og se, om deres handlinger virkelig svarer til det skrig, som har nået mig, eller om de ikke gør; det vil jeg vide." ${ }^{59}$ I dialogen selv synes dommen dog at være blevet afgjort, og på grund af dette begynder Abraham at tale. If. den oprindelige fortælling er Gud en af gæsterne ved Abrahams bord, og måske også ved Lots bord, men ifølge dialogen bliver han tilbage hos Abraham, mens de to budbringere ('engle') går foran. Mens den oprindelige fortælling er en fortælling om den konkrete person Lot og den konkrete by Sodoma, nævnes Lot overhoved ikke i dialogen og Sodoma kun i vers 26. I stedet forhandles et alment rets-

57. Muligvis inklusiv overgangen i vers 17-19, jf. Blum (1984), 400-405. Blandt andet forudsætter v. 19 (ligesom v. 25) deuteronomisk-deuteronomistisk sprog. David M. Carr, Reading the Fractures of Genesis: Historical and Literary Approaches (Louisville: Westminster John Knox Press 1996), 159-161 antager, at v. 19 sammen med 1 Mos 22,15-18 og 26,3bß-5 er semi-deuteronomistiske tilføjelser. På det endelige tekstniveau er 1 Mos 18,16b-22a et afsnit, der hører med til 1 Mos 18,1-22a: 1 Mos 18,16a er den første del af en opbrudsformel, der er typisk for afslutningen af fortællinger, og hvis anden del først kommer i 18,22b; fortælleren har brugt en "split departure formula", som afslutter 1 Mos 18,1-22a, jf. Jonathan D. Safren, "Hospitality Compared: Abraham and Lot as Hosts", i: Lipton (2012), 157-178 (160f).

58. Jf. allerede Julius Wellhausen, Die Composition des Hexateuchs und der historischen Bücher des Alten Testaments (Berlin: de Gruyter $\left.{ }^{4} 1963\right), 25 \mathrm{f}$ og i tilknytning til ham fx Ludwig Schmidt, De Deo. Studien zur Literaturkritik und Theologie des Buches Jona, des Gesprächs zwischen Abraham und Jahwe in Gen 18,22ff und Hi 1 (BZAW143) (Berlin: de Gruyter 1976), 133f; Kratz (2000) 277; Karin Schöpflin, "Abrahams Unterredung mit Gott und die schriftgelehrte Stilisierung der Abrahamgestalt in Gen 18,16b-33", Die Erzväter in der biblischen Tradition (FS Matthias Köckert; BZAW 400), red. Anselm C. Hagedorn \& Henrik Pfeiffer (Berlin/New York: de Gruyter 2009), 93-113 (94). Mht. de følgende argumenter jf. også Blum (1984), 282.

59. Måske kan skriget i 1 Mos 18,20 sammenlignes med akkadisk rigmu. I så fald ville stedet være en parallel til det berømte mesopotamiske Atrahasis-epos. Det ville også tydeliggøre den urhistoriske karakter i 1 Mos 18, jf. Jacob J. Finkelstein, "Bible and Babel: a comparative study of the Hebrew and Babylonian religious spirit", Commentary 26 (1958), 431-444 (436f); Daniel Bodi, The Book of Ezekiel and the Poem of Erra, OBO 104 (Fribourg/Göttingen: Universitätsverlag/Vandenhoeck \& Ruprecht 1991), 159-161. I 1 Mos 18,20-21 hører Gud de plagedes skrig (ș $\left.\mathrm{s}^{\mathrm{e}} q \bar{a} \bar{h}\right)$. Konteksten i Atrahasis taler dog for at forstå rigmu som larm, der forstyrrer guderne, mens juridiske konnotationer ikke synes at spille en rolle. Det synes at være anderledes med det hebraiske begreb șe'āqăh, som forekommer fx også i 2 Mos 3,7 og 22,22.26, og som åbenbart forudsætter et juridisk relevant hjælpeskrig også i 1 Mos 18, jf. van der Wolde (2012). Mht. antropologiske paralleller (Snohomishmyten) jf. Hans Jørgen Lundager Jensen, Den forterende Ild. Strukturelle analyser af narrative og rituelle tekster i Det Gamle Testamente (Aarhus: Aarhus Universitetsforlag 2004), $108 \mathrm{f}$ med fodnote 150 . 
spørgsmål ${ }^{60}$ for at løse en teologisk problemstilling, som i princippet også kunne bringes i anvendelse i forbindelse med Jerusalems fald 587 før Kristus. ${ }^{61}$ Problemet, der diskuteres, er, om Gud, hvis han ikke vil være en vilkårlig tyran, kan tilintetgøre en hel by? ${ }^{62}$

Med dette spørgsmål er det ikke mindre end Eutyfrons problem, der er til stede, og ligesom i Eutyfron udvikles en konkret retssag til et principspørgsmål. ${ }^{63}$ "Må Eutyfron anklage sin far for drab?" udvikles til "Hvad er fromhed hhv. retfærdighed?" "Må Gud tilintetgøre Sodoma?' udvikles til "Bør Gud ikke holde sig til retten og ikke tilintetgøre en hel by?" ${ }^{44}$ Abraham stiller ikke bare retfærdighedsprincippet op over for Gud, men begrunder også sin tænkning og adfærd - jf. retsbegrundelserne ved teologiseringen af loven i de gammeltestamentlige lovsamlinger. ${ }^{65}$ Begrundelsen, som Abraham anfører, lyder som følgende:

Vil du virkelig udrydde retfærdige sammen med uretfærdige? Måske er der halvtreds retfærdige i byen. Vil du så virkelig udrydde dem og ikke tilgive stedet på grund af de halvtreds retfærdige, som er i den? Du kan umuligt handle sådan og slå retfærdige ihjel sammen med uretfærdige, så retfærdige og uretfærdige får samme skæbne. Det kan du umuligt! Skulle han, der dømmer hele jorden, ikke øve ret? ${ }^{66}$ (1 Mos 18,23-25).

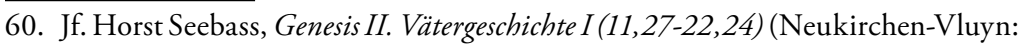
Neukirchener Verlag 1997), 119.

61. Jf. Ezek 16,46-50 og Schöpflin (2009), 95.107

62. Jf. Schmidt (1976), 143: "Kann Gott, wenn er wirklich Gott und nicht ein willkürlicher Tyrann sein will, eine ganze Stadt vernichten?"

63. If. Seebass (1997), 130 kan 1 Mos 18 gælde som en samtale "de Deo"; men han tilføjer: "Nur findet eine solche Abstraktion atl. nicht auf der philosophischen Ebene, sondern auf der eines kontingenten Rechtsfalls statt."

64. "How a decision between Abraham's own, human sense of what is right and some kind of Platonic form of the Good is to be made is difficult to determine. It is commonly asserted that the latter is too abstract and philosophical for ancient Israel, but whichever precise meaning is adopted, the striking feature of the narrative is that the writer depicts Abraham as setting up some standard over against God and by which he dares to judge God's proposed action", Cyril S. Rodd, Glimpses of a Strange Land. Studies in Old Testament Ethics (Edinburgh: Clark 2001), 54.

65. At der appelleres til indsigt og fornuft gælder ikke kun mht. begrundelserne ved teologiseringen af loven, men også mht. 1 Mos 18, jf. Ben Zvi (1992), 35: "Gen 18.23-32 appeals to reason; the dialogue is a reasonable one." Jf. også Cornelis Houtman, "Theodicy in the Pentateuch", Theodicy in the World of the Bible, red. Antti Laato \& Johannes C. de Moor (Leiden: Brill 2003), 151-182 (152): "Gen. 18 reveals reflection on the theodicy problem as well as a passionate craving for a world order in which God's justice is recognisable."

66. Oversættelsen if. 1992-oversættelsen. Mht. det hebraiske udtryk חללה לך jf. Zimmerli (1976), 83; Schöpflin (2009), 96 fodnote 17. 
Som den øverste dommer, hebraisk šofeț, skal Gud holde sig til retten, hebraisk mišpāt. Bag disse formuleringer står verbet šăfat, som betyder "at dømme", men også "at regere", som passer godt til billedet af den kongelige dommer, der 'øver ret', hebraisk 'äsah mišpät, som forekommer her i teksten to gange (1 Mos 18,19.25; sml. 2 Sam 8,15; 1 Kong 3,28; Jer 9,23f). ${ }^{67}$ At øve ret og at dømme en sag betegner en handling, som genopretter den forstyrrede orden i retssamfundet. ${ }^{68}$ Derfor indebærer "at øve ret" et såvel dømmende som frelsende aspekt, idet retten dømmer den uretfærdige og hjælper den retfærdige til at få ret. ${ }^{69}$ Når stormænd regerer med mišpät (Es 32,1), og når Gud ledsager de fattige i mišpatt (Sl 25,9; jf. Ez 34,16), viser sådanne formuleringer, at mispāt ('ret') har en verdens-ordnende karakter. ${ }^{70}$

Denne verdens-ordnende karakter viser, at en retfærdig standard, en retfærdig målestok, anvendes på verden, og verden skal indrettes i overensstemmelse med den. Kulturhistorisk er det derfor vigtigt, at mišpāt ("ret") såvel som parallelbegrebet șadaq ("retfærdighed") kan betegne den rette målestok i konkret forstand som den korrekte vægt, korrekte vægtstene, korrekt rumfang og den retfærdige målestok ved straf.

Korrekt vægt og vægtskåle af ret (mišpāt $)$ hører Herren til, hans værk er alle lodder i posen (Ordspr 16,11). ${ }^{71}$

Retfærdige (șadaq) vægtskåle, retfærdige (şadaq) lodder, retfærdig (sadaq) efa og retfærdig (sadaq) hin skal I bruge (3 Mos $19,36 a) .^{72}$

Jeg gør ret (mišpāt) til målesnor og retfærdighed (sadeq) til lodline (Es 28,17a). ${ }^{73}$

67. Jf. Bo Johnson, “mišpāț”, ThWAT 5 (1986), 93-107 (98). Første gang ordparret "ret og retfærdighed" optræder i Bibelen er i 1 Mos 18,19. Jf. Moshe Weinfeld, Social Justice in Ancient Israel and in the Ancient Near East (Jerusalem/Minneapolis: Magnes Press/Fortress Press 1995), 30.

68. Jf. Gerhard Liedke, "špt", THAT 2 ('2004), 999-1009, 1001.

69. Jf. Liedke ('2004), 1002.

70. Jf. Johnson (1986), 101. mišpāt synes at være tættere forbundet med den sociale og juridiske sfære, mens ședaq synes at være bredere og også omfatte naturens, krigens og kultens sfærer, jf. Schmid (1968), 14-23.

71. Jf. Johnson (1986), 102. Jf. formuleret med ședaq 3 Mos 19,36; 5 Mos 25,15; Ezek 45,10; Job 31,6.

72. Jf. 5 Mos 25,15; Ezek 45,10; Job 31,6. En efa omfattede ca. 20 liter, og en hin knap fire liter, jf. Mathias Winkler, "Maße/Gewichte”, www.wibilex.de (besøgt 15.09.16).

73. Oversættelserne if. 1992-oversættelsen. 
Tugt mig, Herre, men på den rette måde ( $\left.b^{\mathrm{e}} m i{ }^{\mathrm{s}} p \bar{a} \bar{t}\right)$,

ikke i din vrede, så du ikke udsletter mig! (Jer 10,24). ${ }^{74}$

Disse og lignende tekster siger, at vægte, lodder, rumfang, målebånd er indsat i verden med det rette mål, det vil sige ifølge den korrekte målestok - de er ifølge Ordsprogenes bog 16,11 Guds værk. De skal være i orden og svare til en alment accepteret og overalt gældende standard, som ikke skal bøjes. ${ }^{75}$

Grundlæggende for denne interpretation er den kulturhistoriske indsigt $i$, at den menneskelige evne til at vurdere ved hjælp af at måle, veje og tælle befordrer opstån af nye ideer. I for eksempel den ægyptiske religion er ideen om vejningen af hjertet ved den afdødes dom helt afgørende for, at den døde kan komme ind i det hinsidige. ${ }^{76}$ Den dødes hjerte vejes på den ene vægtskål. På den anden befinder sig Ma'at-fjeren, som står for retfærdighed og sandhed. Den religiøse ide om at veje hjertet kan ikke tænkes uden opståen af målingssystemer. Det samme gælder åbenbart for Abrahams tale med Gud og ideen om moralsk realisme, idet retsideen fra nu af kan forstås som en almen målestok, der skal gælde universelt. Allerede i Ezekielbogen siger Israel flere gange ved synet af Jerusalems fald:

Herrens vej er ikke målt af (= er ikke ret, ikke ifølge det rette mål) (Ez $18,25.29 ; 33,17.20)$.

Man kunne også oversætte: "Herrens vej er ikke afbalanceret" eller "er uberegnelig", fordi verbet tākan, som bruges her, betegner en afprøvende måling. ${ }^{77}$ Beskyldningen er altså: Guds vej er ikke rimelig, ikke ifølge det rette mål. Er det sådan? I Ez 20,24f lyder svaret, at Israel ikke har holdt Guds gode retsbestemmelser og derfor har fået dårlige love fra Gud (!), som fører til fordærv:

74. Oversættelse følger her den hebraiske Bibel. Jf. også Jer 30,11; 46,28 samt Johnson (1986), 106.

75. Jf. Schmid (1968), 99. Vedr. et overblik over de judæiske vægtstene jf. Raz Kletter, Economic Keystones. The Weight System of the Kingdom of Judah, JSOT.S. 276 (Sheffield: Sheffield Academic Press 1998).

76. Jf. Jan Assmann, "Das Herz auf der Waage. Schuld und Sünde im Alten Ägypten”, Schuld, red. Tilo Schabert \& Detlev Clemens, Eranos NF 7 (München: Fink 1999), 99-147.

77. Jf. Peter Mommer, “tākan”, ThWAT 7 (1995) 653-657; Moshe Greenberg, Ezechiel 1-20, HThK.AT (Freiburg: Herder 2001), 371f.393f: "hält sich nicht an die Regel". 
Fordi de ikke havde holdt mine lovbud og forkastet mine forordninger (...) så gav også jeg dem forordninger, som ikke var gode, og lovbud, som de ikke kunne leve ved (Ez 20,24f).

Idehistorisk er sætning afgørende. Guds lovbud kan være dårlige, hvilket forudsætter, at de kan måles med en almen standard og vurderes som gode eller onde. ${ }^{78}$ Det er anderledes i det gamle Mesopotamien, hvor der hverken findes refleksioner over lovens væsen eller over uretfærdige retsnormer. ${ }^{79}$ En udvikling hen til denne idé kan dog, måske, findes i det såkaldte babylonske fyrstespejl. Her findes idéen om, at Shamash kan indstifte "fremmed lov" i landet, så fyrster og dommere ikke længere hører på landets egen lov, hvis kongen handler uretfærdigt. $^{80}$

I Første Mosebog 18 bliver Gud eksplicit tituleret som dommer over hele verden. ${ }^{81}$ Dermed viser ret og moral sig som universelle kategorier. Tilsvarende har også ikke-israelitten Job sin egen mišpät, sit egen retskrav som han kan konfrontere Gud med (Job 13,18; 23,4), ${ }^{82}$ og han hævder, at Gud har frataget ham hans eget retskrav (Job 27,2; 34,5f). ${ }^{83}$ Job anklager Gud på følgende måde:

78. It is "possible to evaluate commandments given by God against some standard other than the divine will, and to judge them negatively." Barton (2014), 155. Jf. også Gericke (2012), 417: "So whatever we think about the nature of the deity himself implicit in this text, the divine commands themselves are not assumed to instantiate the property of goodness because they are issued by Yhwh. The good is therefore assumed to exist vis-à-vis the commands with reference to which the commands themselves can be judged to be either good or not."

79. Jf. Michael P. Streck, "Recht. A. In Mesopotamien", RlA 11 (2006-2008), 280285 (284).

80. Jf. Streck (2006-2008), 284. Mht. teksten jf. Wilfred G. Lambert, Babylonian Wisdom Literature (Oxford: Clarendon Press $\left.{ }^{3} 1975\right), 112$ linje 9f.

81. Abrahams spørgsmål fra 1 Mos 18,25 oplyser derfor, at Det Gamle Testamente kender til en retside, der har universel rækkevidde og det almindelige menneske i tankerne, jf. formuleret som et åbent spørgsmål ved Friedrich Horst, "Naturrecht und Altes Testament", i: idem, Gottes Recht. Gesammelte Studien zum Recht im Alten Testament (München: Kaiser 1961), 235-259 (235). Horst afviser betegnelsen naturret mht. Det Gamle Testamente, fordi kilden til loven alene findes i Gud (ibidem 258). Jf. også Henry S. Gehman, "Natural Law and the Old Testament", Biblical Studies in Memory of H.C. Alleman, red. Jacob M. Myers, Otto Reimherr \& Howard N. Bream (Locust Valley, NY: Augustin 1960), 109-12 (122). Det afgørende er $\mathrm{dog}$, at loven gælder universelt og ikke er afhængig af opfattelserne, ligesom allerede Aristoteles påpeger i den nikomacheiske etik 1135b, jf. fx Otfried Höffe, Aristoteles (München: Beck $\left.{ }^{3} 2006\right), 232$.

82. Jf. Johnson (1986), 97. Jf. også Abimelek fra Gerar i 1 Mos 20,4.

83. Jf. Johnson (1986), 100. Job konfronteres til gengæld med spørgsmålet, om han vil ødelægge Guds mišpāt (Job 40,8). Det er ikke meningsfuldt her at skelne mellem en juridisk og politisk dimension af mišpa $\bar{t} t$ if. Sylvia H. Scholnick, "The Meaning of mišpat in the Book of Job", JBL 101 (1982) 521-529. 
Den retskafne og den uretfærdige udsletter han! (Job 9,22b).

I form af en beskyldning formulerer Job den almene fordring, at den retfærdige ikke må udslettes sammen med den uretfærdige. I det mesopotamiske Erra-Epos beskylder vesiren Ishum pestguden Erra for at straffe menneskene uden forskel:

104 Helt Erra, den retskafne lod du dø,

105 den uretfærdige lod du dø.

106 den der har syndet mod dig lod du dø,

107 den der ikke har syndet mod dig lod du dø (Erra-Epos IV 104107). ${ }^{84}$

Noget tilsvarende sker i det mesopotamiske Gilgamesh-epos, der bl.a. fortæller om syndfloden, og som de israelitiske skrivere har haft kendskab til, da de skrev den bibelske syndflodsfortælling. Her beslutter guderne sig for at bringe en voldsom oversvømmelse over menneskene, og det er kun Utnapishtim, den babylonske Noah, der overlever ved at bygge sig en ark. Efter syndfloden er overstået, anklager den gode visdomsgud Ea kongeguden Enlil med følgende:

Du, den viseste af guder, krigeren,

hvordan kunne du så ubetænksomt iværksætte syndfloden?

Lad synderen sone sin brøde,

lad forbryderen lide sin straf! (Gilgamesh XI 183-186). ${ }^{85}$

I alle disse tilfælde bliver det tydeligt, at guddomme kan konfronteres med et princip og en målestok, der ikke er vilkårlig. Abraham opfinder ikke nogle nye regler, men uddrager almengyldige konsekvenser af gamle grundprincipper. ${ }^{86}$ Når Gud åbenbarer sig selv som retfærdig dommer i flere tekster ( $\left(f_{x} S 1\right.$ 9,5) og har indrettet verden på en retfærdig måde - så kan det også fordres, at Gud skal holde sig til sin rolle som øverste dommer og skaber. Abraham holder bare denne fordring og denne målestok op imod Gud, som han selv har lagt på sig selv og på verden. Gud skal holde sig til reglerne - også hvis de er

84. Oversættelsen følger TUAT III/4, 797. Jf. også Johannes U. Ro, Poverty, Law, and Divine Justice in Persian and Hellenistic Judah (Atlanta: SBL 2018), $103 \mathrm{f}$.

85. Oversættelse if. Ulla S. Koch \& Aage Westenholz, Gilgamesh. Enuma Elish. Guder og mennesker i oldtidens Babylon (Højbjerg: Univers 2015), 130f. Verstælling if. Andrew R. George, The Babylonian Gilgamesh Epic. Introduction, Critical Edition and Cuneiform Texts (Oxford: Oxford University Press 2003), $714 \mathrm{f}$.

86. "Abraham stellt hier keine neuen Regeln auf, sondern führt gegen Gott einen alten Grundsatz ins Feld", Schmidt (1976), 145. 
Guds egne - ligesom han selv fordrer af menneskene at de skal gøre. "To play according to the rules", det gælder også og især Gud - sådan siger Abraham - om end meget ydmygt og høfligt.

I det følgende stiller Abraham flere spørgsmål og forhandler i flere trin og købslår om Sodomas tilintetgørelse. ${ }^{87}$ Abrahams spørgsmål er, om Gud ville ødelægge byen, selv hvis der skulle findes et vist antal retfærdige deri. Gud accepterer, og Abraham forhandler antallet af de mulige retfærdige ned fra 50 til $10 .{ }^{88}$ Mens Eutyfron prøver at svare på Sokrates kloge spørgsmål kort og prægnant, men til sidst opgiver og løber væk, forbliver Gud ved alle Abrahams retfærdige spørgsmål temmelig afslappet og godkender, hhv. tilslutter sig, på en lige så kort og prægnant måde - som om han ville have ønsket og forventet sådan en indsats. ${ }^{89}$ Allerede før Abraham overhovedet begynder at tale, tilbyder Gud Abraham muligheden for at spørge, som han gør: "Skulle jeg skjule for Abraham, hvad jeg har i sinde at gøre?"90 Gud lader

87. Mht. handel- og købslå-motivet i 1 Mos 18 jf. kritisk Nathan MacDonald, "Listening to Abraham - Listening to Yhwh: Divine Justice and Mercy in Genesis 18:16-33”, CBQ 66 (2004), 25-43 (30-35); Hans Jørgen Lundager Jensen, “Abraham, høflighedens ridder", DTT 74 (2011), 3-21, især 13-15.

88. Inden for rettens område gælder 50 og 10 mænd som de mindste retsenheder (jf. 2 Mos 18,21.25; 5 Mos 1,15; Rut 4,2). Jf. også Am 5,3 og Schmidt (1976), 151. I 1 Mos 19 tænkes dog på individet, idet Lot og hans familie reddes, jf. Yitzhak Peleg, "Was Lot a Good Host? Was Lot saved from Sodom as a Reward for His Hospitality?”, i: Lipton (2012), 129-156; Safren (2012), 157-178. Alligevel kan den enkelte, her Lot, ikke redde hele samfund, jf. Ez 14 og Diana Lipton, "The Limits of Intercession: Abraham Reads Ezekiel at Sodom and Gomorrah", i: idem (2012), 25-41. Tværtimod er det de retfærdiges fællesskab og antal, selvom det er lille (mindst ti), der alene kan redde en ond by, jf. fx J. Alberto Soggin, Das Buch Genesis. Kommentar (Darmstadt: Wissenschaftliche Buchgesellschaft 1997), 279. Jf. også Ro (2018), 117, der mener, at 1 Mos 18 er ældre end Ez 14 og 18: “God's justice is no longer realized by bringing total destruction to a sinful society (as in Amos 8:1-2) or by assigning merely individual retribution (as in Ezek 14:12-20 and Ezek 18), but by being patient with a sinful society to protect the lives of a righteous few. This is a dramatic change in the theological paradigm of divine justice.” Jf. også Nahum M. Sarna, Genesis (Philadelphia: Jewish Publication Society 1989), 133. Schöpflin (2009), 99 fremhæver, at Ez 14 bedre svarer til 1 Mos 19. I den senere jødedom er det nødvendigt med mindst ti personer for at danne en jødisk synagogal menighed (minjan).

89. Jf. Benno Jacob, Das Buch Genesis (Stuttgart: Calwer 2000), 448-450; Roshwald (1989), 155-157. Indsatsen her har måske endda karakter af forbøn, jf. fx Lipton (2012) og især mht. 4 Mos 16,22 (jf. også 1 Mos 20,17) Joseph Blenkinsopp, "Abraham and the Righteous of Sodom", JJS 33 (1982) 119-132 (126). Dog findes der også indvendinger imod forbøn-tesen, jf. fx Schöpflin (2009), 101: "Die Sprechhaltung Abrahams ist formal keine bittend-betende, sondern eine anfragende, die den disputierenden Grundzug beinahe vornehm verdeckt. Ihr haftet dabei etwas Abstraktes, Akademisches an.”

90. Oversættelsen if. 1992-oversættelsen. 
Abraham vide, at han har i sinde at udslette byen. ${ }^{91}$ Abraham skal jo blive til et stort folk og selv øve ret og retfærdighed (la sa $s o t s^{\mathrm{e}} d \bar{a} q \bar{a} h \hat{u}$ mišpạt, v. 19). ${ }^{92}$ Kort efter spørger Abraham, om Gud, som verdens øverste dommer, ikke bør holde sig efter retten (mišpāt)? Formuleringerne om den menneskelige og den guddommelige retfærdighed, så kort efter hinanden, ligner hinanden meget og viser, at begge, Abraham og Gud, fastholder den fordring at holde sig til målestokken "ret og retfærdighed". ${ }^{93}$ På tekstens overflade ser det ud, som om Abraham undersøger, om han, Gud, handler retfærdigt. Bag kulisserne undersøger Gud også Abraham, om han, Abraham, kan anlægge målestokken "ret og retfærdighed" også i besværlige tilfalde, nemlig over for den øverste dommer, Gud. Hvis kristendommen - og her for eksempel Kierkegaard - gerne fremhæver, at Abraham er troens fader ifølge 1 Mos 15 og 22, kan man også sige, at Abraham ifølge kapitel 18 viser sig som retfærdighedens fader. ${ }^{94}$ I denne dialog får Abraham at vide, at retfærdigheden er en instans, som også Gud holder sig til. Som retfærdighedens fader skal Abraham viderebringe denne viden til de efterfølgende generationer og alle folkeslag.

91. Derefter begynder Abraham at tale, et enkeltstående tilfælde, fordi det ellers er Gud, der tager ordet først under en samtale med Abraham, jf. Schöpflin (2009), 94. 92. Jf. også Ez 18,5.19.21.27; 33,14.16.19.

93. Jf. Joze Krašovic, Reward, Punishment, and Forgiveness. The Thinking and Beliefs of Ancient Israel in the Light of Greek and Modern Views, VT.S 78 (Leiden: Brill 1999), 61f og Roshwald (1989), 149: "In this sense, the speck of dust becomes God's equal.” Mens det i Sl 72 og andre steder er kongen, der skal øve ret og retfærdighed, bliver kongens rolle her overført til Abraham, jf. fx Weinfeld (1995), 216.

94. "Nicht als der Vater des Glaubens wird Abraham hier verstanden (wie in Gn 15,6), sondern als Vater der Gerechtigkeit"; Claus Westermann, Genesis. 2. Teilband. Genesis 12-16, BK I/2 (Neukirchen-Vluyn: Neukirchener Verlag 1981), 351. 